\title{
Can Attitudes, Subjective Norms and Behavioral Control Perceptions Influence The Visitors Interest in Buying at Department Stores in Bandung?
}

\author{
Raeni Dwi Santy \\ Program Studi Manajemen \\ Universitas Komputer Indonesia \\ Bandung, Indonesia \\ raeny.dwisanty@email.unikom.ac.id
}

\author{
Mirna Zulianti \\ Program Studi Manajemen \\ Universitas Komputer Indonesia \\ Bandung, Indonesia \\ mirna.zulianti@email.unikom.ac.id
}

\begin{abstract}
The purpose of this study is to determine consumer behavior in these case attitudes, subjective norms, perception of control behavior, and buying interest of Mall customers, as well as to determine the effect of consumer behavior in these regard, subjective norms and perceptions of behavioral control on buying interest. This research uses descriptive and verification methods. The analytical method used is a method of multiple regression analysis, using primary data by distributing a series of questionnaires to department store visitors in Bandung. Samples were taken using simple random sampling with a sample of 90 people from the population of 870 . This study found that attitudes, subjective norms and perception of behavioral control have a significant effect on purchase intentions both partially and simultaneously.
\end{abstract}

Keyword- subjective norms, perceived behavior control, purchase intention.

\section{INTRODUCTION}

When the community decides where they will shop in department stores, they are faced with a variety of choices because many department sores offer their products with various attachments to lure visitors. Even so, people have different attitudes. With the attitude of the community, the company can find out what I can make a determinant for someone buying a product. Schifman and Kanuk in Bilson Simamora stated that attitude is an expression of feeling (inner feeling), which reflects whether someone is happy or not happy, likes or dislikes, and agrees or disagrees with an object. The object in question can be in the form of a brand, service, retailer, certain behavior, and others [1]. Besides the attitude, the shopping community can be determined by subjective norms and the perception of behavior control. Subjective norms are defined as individual perceptions of social pressure to do or not to conduct a behavior [2] Subjective norms are determined by a combination of individual normative belief and motivation to comply, Ajzen describes perceived behavioral control as a function based on belief called control beliefs, namely individual beliefs about the presence or absence of factors that support or prevent individuals from appearing a behavior [2].

Femka Dyan et al, explained that the research results revealed that attitudes, subjective norms and behavioral control had a significant positive effect on taxpayer compliance. This is because these three components interact and become determinants of intentions / intentions which in turn determine whether the behavior in question will be done or not. Seyed Nasir Ketabi et al got the findings in his research, the structural model that was conducted provided strong support for online shopping, roles, cognitive behavioral control, recognized behavioral control and subjective behavior for online shopping [3]. Vishal Soodan et al explained that the results of his research showed that there was a positive relationship between consumer attitudes and subjective norms [4]. This may be due to the fact that consumer attitudes have developed with social norms in society. Dwinta Andryani got the discovery that there was a positive influence on attitudes, subjective norms and perceived behavioral control on the desire to buy food, this showed the positive impact of halal food on customers was a positive factor in the desire of non-Muslim customers to buy [5]. Munandar explained that the findings produced partially by the attitude of influencing intentions, as well as subjective norms partially affect intentions [6]. The results of the analysis carried out show that subjective norms have a greater contribution in influencing consumers' intention to use Islamic banking products at Sharia Banks in Lhokseumawe city compared to attitudes. This means that consumers are more bound to their referrals in determining their intention to use Islamic banking products in Aceh Sharia Banks in the city of Lhokseumawe.

Because in the study there was no discussion of attitudes, subjective norms and behavioral control perceptions in influencing department store visitors buying interest. The purpose of this study was to determine the effect of attitudes, subjective norms and behavioral control perceptions on the visitors buying interest. To support, we use the description and verification method. Hopefully this method is useful because it can determine the influence of each attitude of consumer behavior such as attitudes, subjective norms and perception of behavioral control on buying interests.

\section{METHOD}

The sample used in this study were 90 people from the population of 870 ddepartment store visitors in Bandung. The 
sampling technique in this study uses a non-probability sampling method, which is choosing a sample not randomly so that not every member of the population has the same opportunity to become a member of the sample. The type of method used was purposive sampling where the selection of respondents was selected based on certain criteria, namely consumers who had shopped at the Department Store in Bandung at least 2 times in the last 2 months (July September) who were over 17 years old and residing in Bandung. Data analysis techniques used are:

\section{Regression Analysis}

The analysis technique used is multiple linear regression analysis with the following formula [7]:

$$
Y=B o+B 1 X 1+B 2 X 2 \ldots+B n X n+\varepsilon
$$

Where:

$\mathrm{Y}=$ Dependent Variables

$\mathrm{X} 1=$ Attitude Variable

$\mathrm{X} 2=$ subjective norm variables

$\mathrm{X} 3=$ Variable perceived behavior control

$\mathrm{A}=$ Constants

$\beta 1=$ Linear variable regression coefficient

$B 2=$ Linear regression coefficient of subjective norm variables

B3 = Linear regression coefficient variable perceived behavior control

Hypothesis:

H1: Attitudes, subjective norms and behavioral control perceptions have an effect on buying interest in visiting Department Stores in Bandung.

H2: Attitudes affect the purchase intention of department store visitors in Bandung.

H3: Subjective norm affects the purchase intention of department store visitors in Bandung.

H4: perceived Behavioral control affects the purchase intention of department store visitors in Bandung.

\section{RESULT}

From the results of the study obtained data about the characteristics of respondents as shown in table 1:

TABLE 1. DESCRIPTIVE ANALYSIS RESULT

\begin{tabular}{|l|c|c|}
\hline $\begin{array}{c}\text { Respondent based } \\
\text { on : }\end{array}$ & Frequency & Percentage (\%) \\
\hline $\begin{array}{l}\text { Gender : } \\
\text { Male }\end{array}$ & 37 & \\
Female $\quad$ Total & 53 & 41.11 \\
& 90 & 58.89 \\
\hline Age $;$ & & 100 \\
<25 y & 42 & 46.67 \\
$26-35$ y & 27 & 30.00 \\
$36-45$ y & 14 & 15.55 \\
$>45 y$ & 7 & 7.78 \\
\hline
\end{tabular}

\begin{tabular}{|c|c|c|}
\hline $\begin{array}{l}\text { Respondent based } \\
\text { on : }\end{array}$ & Frequency & Percentage (\%) \\
\hline Total & 90 & 100 \\
\hline $\begin{array}{l}\text { Income : } \\
\leq 1 \text { million } \\
>1-2 \text { million } \\
>2 \text { juta }-3 \text { million } \\
>3 \text { million } \quad \text { Total }\end{array}$ & $\begin{array}{c}1 \\
3 \\
12 \\
74 \\
90\end{array}$ & $\begin{array}{c}1.11 \\
3.33 \\
13.33 \\
82.23 \\
100\end{array}$ \\
\hline $\begin{array}{l}\text { Shopping frequency } \\
\text { in the last six months } \\
: \\
0-3 \\
3-6 \\
>6\end{array}$ & $\begin{array}{c}0 \\
52 \\
38 \\
90\end{array}$ & $\begin{array}{c}0 \\
57.78 \\
42.22 \\
100\end{array}$ \\
\hline $\begin{array}{ll}\text { Job: } & \\
\text { Employee } & \\
\text { Entrepreneur } & \\
\text { Housewife } & \\
\text { Civil Servant } & \\
\text { Student } & \\
\text { Others } & \\
& \text { Total }\end{array}$ & $\begin{array}{c}32 \\
11 \\
8 \\
15 \\
20 \\
4 \\
90\end{array}$ & $\begin{array}{c}35.56 \\
12.22 \\
8.89 \\
16.67 \\
22.22 \\
4.44 \\
100\end{array}$ \\
\hline
\end{tabular}

The results of the Multiple Linear Regression Calculation are as shown in table 2:

TABLE $2 . \quad$ VERIFICATION ANALYSIS RESULT

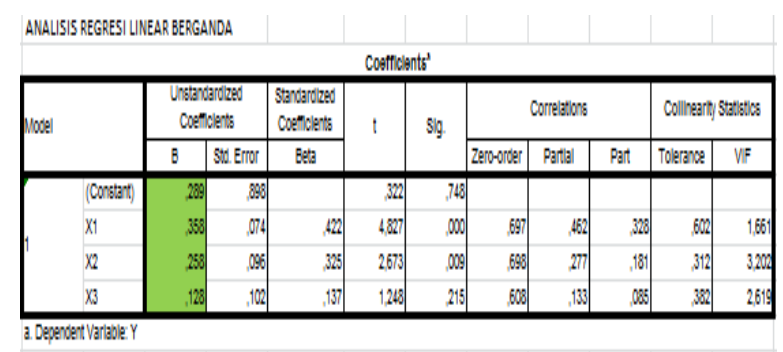

According to the table obtained a constant value of 0.289 , regression coefficient values of attitude variables $(\mathrm{X} 1)=$ 0.358 , subjective norm $(\mathrm{X} 2)=0.258$ and perceived behavioral control $(\mathrm{X} 3)=0.128$, resulting in the regression equation as follows:

$$
Y=0,289+0,358 X 1+0,258 X 2+0,128 X 3
$$

From the regression equation, it can be seen that the three regression coefficients are positively marked, indicating that the higher the attitude, subjective norms and behavioral control perceptions, the higher the buying interest of visitors. Statistically, the values in the multiple linear regression equation above can be interpreted as follows:

1. A constant of 0.289 indicates the magnitude of the score of the visitor's buying interest when Attitudes, Subjective Norms and Perceptions of Behavioral Control are simultaneously valued at 0 .

2. The regression coefficient for attitude is 0.358 with a positive sign indicating that each occurrence of an attitude score and other independent variables is constant, 
it is indicated that the visitor's buying interest will increase by 0.358 .

3. The regression coefficient for Subjective Norms is 0.258 with a positive sign indicating that each occurrence of an increase in the Subjective Norm and other independent variables is considered constant, predicted to increase visitor buying interest by 0.258 .

4. The regression coefficient for Perception of Behavioral Control is 0.128 with a positive sign indicating that every occurrence of an increase in Perception of Behavior Control and other independent variables is considered constant, predicted to increase visitor buying interest by 0.128 .

5. So based on the regression test, it can be concluded that the attitude variables, subjective norms and perceptions of behavioral control are positive, so that each increase will also increase the variable interest in buying visitors.

\section{DISCUSSIONS}

Based on the result above, it can be concluded that:

H1: Attitudes, subjective norms and behavioral control perceptions influence the buying interest of visitors to Department Stores in Bandung.

This simultaneous hypothesis was tested using Test F, it can be seen that the value of Fcount $=43.736$ is greater than Ftable $=2.70$ then $\mathrm{H} 0$ is rejected and $\mathrm{H} 1$ is accepted, it means that there is influence of attitude variables (X1), subjective norm (X2) and behavioral control (X3) on variable simultaneous buying interest of visitors.

$\mathrm{H} 2$ : Attitudes affect the purchase intention of department store visitors in Bandung.

Based on the calculation, $t$ count is greater than $t$ table $(4,827>1,988)$, then H0 is rejected and accepts H1. This means that partially there is a significant influence on attitudes towards buying interest of visitors.

Attitude variables have a significant effect on the buying interest of visitors because they have an error probability value of 0.000 (below 0.05 ), so that the attitude is said to have a positive influence on the buying interest of visitors, meaning that the better the attitude of consumers at the department store, the higher interest in buying visitors at the department store. This shows that attitude is an overall concept evaluation carried out by visitors. Evaluation can be created by an affective system in the form of emotions, feelings, moods and immediate and direct responses to certain stimuli. This attitude can be in the form of interest in shopping at department stores, the preference for products offered at department stores, the pleasure in shopping for products at department stores and the confidence in the benefits of department store products in Bandung. If there are positive signs on interests, likings, pleasures and consumer confidence, it will cause visitors to buy the products. This finding is in line with the opinion of Simamora which states that attitude is an evaluation that can be created by the affective system in the form of emotions, feelings, moods and immediate and direct responses to certain stimuli [8]. If the emotions, feelings, and mood of the consumer are positive, it will generate interest to buy a product / service.

According to Ajzen attitudes toward behavior are one of the determinants of intention formation [2]. Attitudes towards the defined behavior of Ajzen as a degree of positive or negative assessment of individuals towards certain behaviors [2]. The above statement is also supported by the results of previous studies. The results showed that this was in line with the research conducted by Wibowo and Kumolohadi with the results saying that the attitude towards the curriculum was positively related to the intention to enroll in the Psychology Professional Education Program of UII, meaning that if the attitude towards the curriculum is high then the intention to register is also high, and vice versa [9].

Based on the theory put forward by Ajzen and also the results of previous studies, it can be seen that attitudes can influence individual intentions in carrying out certain behaviors [2].

H3: Subjective norm affects the purchase intention of department store visitors in Bandung.

Based on the calculations performed, $\mathrm{t}$ count is greater than $t$ table $(2,673>1,988)$, then $\mathrm{HO}$ is rejected and accepts H1. This means that partially, there is a subjective norm influence on buying interest significantly.

According to Ajzen subjective norms are individual perceptions of social pressure to do or not to conduct a behavior [2]. The results of the study Julprima explained the low intention of condom use in premarital sexual intercourse of adolescents is more caused by their perception that things are expected by significant others and they are motivated to comply with these expectations [10]. In other words, the results of this study show subjective norms influence the intention of condom use in adolescents.

Based on the theory put forward by Ajzen and also the results of previous studies, it can be seen that subjective norms can influence an individual's intention to perform certain behaviors [2].

Subjective norm variables significantly influence the visitors buying interest because they have an error probability value of 0,000 (below 0.05), so that subjective norms have a positive effect on visitor buying interest, meaning that the better the subjective norm in department stores, the higher the buying interest. department store visitors. This shows that subjective norms (subjective norm) are the extent to which a person has the motivation to follow people's views on the behavior that will be done (normative belief). Subjective norms can be in the form of most people making purchases as a consideration for visitors in buying at Bandung department stores, visitors reconsider shopping plans if most people make purchases at Bandung department stores, more and more people make purchases at department stores to consider visitor policies in making department purchases store and more and more people who make purchases at department stores will be a consideration of the benefits visitors get when shopping at department stores. If someone feels it is his/her 
personal rights to determine what he/she will do and can be determined by other people around him/her, then he will feel that the person's view of the behavior that will be done is appropriate, so that it will generate interest in buying a product / service. This finding is in line with the opinion of Ajzen stating that if an individual feels it is his personal right to determine what he will do and can be determined by other people around him/her, then he/she will feel that the person's view of the behavior he is going to do is appropriate, so it will generate interest in buying a product / service [2].

H4: Perceived Behavioral control affects the purchase intention of department store visitors in Bandung.

Based on calculations obtained, $\mathrm{t}$ count is greater than $\mathrm{t}$ table $(2,248<1,988)$, then $\mathrm{H} 0$ is rejected and accepts $\mathrm{H} 1$. This means that partially there is a significant effect of the Behavioral Control Perception variable on buying interest. According to Ajzen perceived behavioral control (PBC) or perceived behavioral control as individual perceptions of the ease or difficulty of carrying out certain behaviors [2]. In Asrori's research PBC is said to have a significant positive relationship to tax avoidance intentions [11]. Perceived propriety control is a condition that indicates the ease or difficulty of taking action and is considered a reflection of past experience in addition to obstacles or anticipated obstacles.

The perceived behavior control in this study was measured from the confidence control indicator and access to control factors. The results of this study indicate that perceived control has a significant effect on the buying interest of visitors at Bandung department stores, thus it can be stated that there is a perceived influence of behavior control on buying interest of visitors to department stores in Bandung. This result is in accordance with the research conducted by Jessvita which states that behavioral control perception variables have a positive effect on consumer purchase intention [12]. This study means that the better the perception of behavioral control at department stores, the higher the interest in buying department store visitors. This is due to the tendency of Bandung department store visitors to buying interests.

The perceived behavioral control variable has a significant effect on visitor buying interest because it has an error probability value of 0,000 (below 0.05 ), so that perceived behavioral control has a positive effect on visitor buying interest, meaning that the better perceived behavioral control at the department store, the higher the interest buy department store visitors. This shows that perceived behavioral control are beliefs that an individual has carried out certain behaviors, then an individual estimates his ability to have the ability to carry out that behavior. This behavior can be in the form of visitors not relying on anyone when I decide to shop at department stores at least once in the future, visitors will shop at department stores, whenever they want, and there is no obstacle to shopping at department stores, so if individuals have the ability to carry out the behavior, it will cause interest to buy. This finding is in line with Chiou 's opinion stated that that buying interest is seen as something that immediately precedes behavior determined by perceived behavioral control [13]. This shows that the better perceived behavioral control, the more it will increase the buying interest in visitors.

The results of this study are in line with Ajzen's Theory of planned behavior [2]. Based on this theory, factors of perception of behavioral control have characteristics to strengthen and weaken interest. This theory distinguishes between three types of beliefs, namely behavioral belief, normative belief and control belief, where it relates to the construction of attitudes, subjective norms and perceived behavioral control. What is suggested from this theory is related to the perception of behavioral control, this theory is reflected in this study. In this research, when someone believes that he/she has enough resources, skills, or the opportunity to buy products, he/she will have a strong buying interest to show that behavior. Controls that individuals have can be in the form of availability of resources, skills, or even opportunities to show certain behaviors. Thus, it can be seen that there is a strong positive relationship between perceptions of behavioral control over buying interests.

\section{CONCLUSION}

Attitudes, subjective norms and perceived behavioral control simultaneously affect the buying interest of department store visitors in Bandung. Attitudes, Perceived Behavioral control and subjective norms have a partial effect on the visitors buying interests at department stores in Bandung.

\section{ACKNOWLEDGEMENT}

The authors would like to thank the Unikom Rector Dr. Ir. H. Eddy Soeryanto Soegoto., and Dean of the Faculty of Economics and Business Prof. Dr. Hj. Dwi Kartini Yahya., SE., Spec. Lic, who have given the opportunity to do this research.

\section{REFERENCES}

[1] Schiffman, Leon.G. dan Kanuk, Leslie. 2002. Perilaku Konsumen. Jakarta : PT. Indeks

[2] Ajzen, Icek, 2005, Attitudes, Personality and Behavior, (2nd edition), Berkshire, UK: Open University Press-McGraw Hill Education

[3] Seyed Nasir Ketabi, Bahram Ranjbarian, \& Azarnoush Ansari. (2014). Analysis of the Effective Factors on Online Purchase Intention through Theory of Planned Behavior. International Journal of Academic Research in Business and Social Sciences Vol. 4, No. 4 ISSN: 2222-6990

[4] Vishal Soodan \& Akhilesh Chandra Pandey (2016) Evaluating the Impact of Consumers' Attitudes and Subjective Norms on Purchase Intentions in FMCG Purchases. International Research Journal of Social Sciences. Vol. 5(4), 21-25, April (2016) EISSN 2319-3565

[5] Dwinta Andryani \& Kurniawati (2015). Pengaruh Attitude, Subjective Norm, Perceived Behavioral Control Pelanggan Non-Muslim Terhadap Intention To Purchase. Seminar Nasional Cendekiawan 2015 ISSN: 2460-8696 hal, 674-681

[6] Munandar, (2014). Pengaruh Sikap Dan Norma Subyektif Terhadap Niat Menggunakan Produk Perbankan Syariah Pada Bank Aceh Syariah Di Kota Lhokseumawe. JURNAL 
VISIONER \& STRATEGIS. Volume 3, Nomor 2, ISSN : 23382864 p. $73-80$

[7] Arcana, N., 2009, Pengantar Statistik II untuk Ekonomi Bagian Inferensial, Surabaya: Fakultas Ekonomi Universitas Katolik Widya Mandala Surabaya

[8] Simamora, M. 2002. Perilaku konsumen. Jakarta: PT. Gramedia. Kondom dalam Hubungan Seksual Pranikah. Skripsi. Depok: Fakultas Psikologi UI.

[9] Wibowo,T.G., \& Kumolohadi, RR.R. (2008). Hubungan Antara Sikap Terhadap Inovasi Produk Dan Kepuasan Konsumen Dengan Loyalitas Merek.

[10] Julprima, H. 1991. Sikap, Norma Subjektif, dan Intensi Remaja terhadapPenggunaan

[11] Asrori. 2011. Psikologi Remaja-Perkembangan Peserta Didik. Cetakan ketujuh, Jakarta: PT. Bumi Aksara

[12] Jessvita Anggelina J.P dan Edwin Japarianto (2014). Analisis Pengaruh Sikap, Subjective Norm dan Perceived Behavioral Control Terhadap Purchase Intention Pelanggan. Jurnal Strategi Pemasaran. Vol. 2, No.1, hal. 1-9.

[13] Chiou, Jyh Shen, 2008, The Effects of Attitude, Subjective Norm, and Perceived Behavioral Control on Consumers' Purchase Intentions: The Moderating Effects of Product Knowledge and Attention to Social Comparison Information, Proc. Natl. Sci. Counc. ROC (C), Vol. 9, No. 2, pp. 298-308 